\title{
Pengaruh variasi komposisi bahan pengisi carbon black dan silika pada sifat viskoelastis kompon karet untuk tread ban
}

\section{The effect of carbon black and silica filler composition variation to the viscoelastic properties of tire tread rubber compound}

\author{
Dewi Kusuma Arti*, Riastuti Fidyaningsih, Amilatin Rohmah, Lies A. Wisojodharmo, \\ Henny Purwati \\ Pusat Teknologi Material-BPPT, Gedung 224 Puspiptek Serpong, Tangerang Selatan, 15314, Indonesia \\ *Penulis korespondensi. Telp. +6221 75791324, Faks. +6221 75791327 \\ E-mail: dewikusuma.psu@gmail.com
}

Diterima: 24 Oktober 2017 Direvisi: 11 Maret 2018 Disetujui: 13 Maret 2018

\begin{abstract}
The rheological and viscoelastic properties of the rubber compound, especially for tire tread compound, are strongly influenced by the type of rubber and the filler used. These two properties greatly affect the final rubber product especially in terms of its mechanical properties. In the development of a product, research on these two properties is essential to obtain the optimum formulation. This study was aimed to determine the rheological and viscoelastic properties of tire compound using natural rubber (NR) and butadiene rubber (BR) materials by varying the composition of the carbon black and silica fillers. The base material of NR and BR with a ratio of 85/15 phr was mixed using a kneader device, while the ratio of carbon black/ silica fillers was: 50/0, 40/10, 25/25, 10/40, and 0/50 phr. The rheology and viscosity properties were tested by using rubber process analyzer (RPA) TA Instrument Elite and dynamic mechanical analyzer (DMA) 7100 Hitachi. RPA testing was performed at frequency variation from $0.01-50 \mathrm{~Hz}$ at a temperature of $100^{\circ} \mathrm{C}$ with fixed amplitude 10 and an amplitude variation from 0.05 3.59 at a temperature of $90^{\circ} \mathrm{C}$ with a fixed frequency of $1 \mathrm{~Hz}$. While viscoelastic testing with DMA was done using the tension-compression method with test temperature range at $-80^{\circ}-80^{\circ} \mathrm{C}$. RPA test results showed the addition of silica affects the interaction between fillers indicated by differences in Payne effect. The energy of dissipation also shows a tendency to lower the heat build up, improve the mechanical properties and improve the abrasion resistance of rubber products with the addition of silica as the filler. It is also supported by DMA test results that showed wet skid resistance in silica addition comparable to the use of carbon black only and also increased rolling resistance significantly.
\end{abstract}

Keywords: carbon black, silica, viscoelastic, rheology, Payne effect.

\begin{abstract}
ABSTRAK
Sifat reologi dan viskoelastis pada kompon karet, terutama kompon tread ban, sangat dipengaruhi oleh jenis karet serta bahan pengisi yang digunakan. Kedua sifat ini sangat mempengaruhi hasil akhir dari produk karet terutama dalam hal sifat mekanisnya. Dalam pengembangan suatu produk, penelitian mengenai kedua sifat ini sangatlah penting untuk memperoleh formulasi yang optimum. Penelitian ini bertujuan untuk mengetahui sifat reologi dan viskoelastis dari kompon tread ban menggunakan bahan dasar karet alam (NR) dan butadiene rubber (BR) dengan memvariasikan komposisi bahan pengisi yaitu carbon black dan silika. Bahan dasar NR dan BR dengan rasio 85/15 phr dicampur dengan menggunakan alat kneader, sementara rasio bahan pengisi carbon black/silika adalah: 50/0, 40/10, 25/25, 10/40, dan 0/50 phr. Sifat reologi dan viskositas diuji dengan menggunakan rubber process analyzer (RPA) TA Instrument Elite dan dynamic mechanical analyzer (DMA) 7100 Hitachi. Pengujian RPA dilakukan dengan menggunakan variasi frekuensi dari $0.01-50 \mathrm{~Hz}$ pada suhu $100^{\circ} \mathrm{C}$ dengan amplitudo tetap 10 dan variasi amplitude dari 0,05-3,59 pada suhu $90^{\circ} \mathrm{C}$ dengan frekuensi tetap $1 \mathrm{~Hz}$. Sedangkan pengujian viskoelastis dengan DMA dilakukan menggunakan metode tension-compression dengan rentang suhu pengujian pada $-80^{\circ}-80^{\circ} \mathrm{C}$. Hasil uji RPA menunjukkan penambahan silika mempengaruhi interaksi antar bahan pengisi yang ditunjukkan dengan perbedaan pada efek Payne. Energi disipasi juga menunjukkan kecenderungan menurunkan heat build up, meningkatkan sifat mekanis dan memperbaiki ketahanan abrasi pada produk karet dengan tambahan silika sebagai
\end{abstract}


bahan pengisi. Hal ini juga didukung oleh hasil uji DMA yang menunjukkan wet skid resistance pada penggunaan silika yang sebanding dengan penggunaan carbon black saja dan rolling resistance yang meningkat signifikan dengan penambahan silika.

Kata kunci: carbon black, silika, viskoelastis, reologi, efek Payne.

\section{PENDAHULUAN}

Bahan pengisi yang biasanya digunakan dalam formulasi kompon karet yaitu carbon black dan silika. Kedua jenis bahan ini memiliki perbedaan sifat yang dapat mempengaruhi homogenitas pada proses pencampuran. Hal ini disebabkan oleh proses aglomerasi dari kedua bahan pengisi tersebut. Hal ini sesuai dengan teori yang disampaikan Seyvet dan Navard (2000) yang menyatakan bahwa interaksi antar bahan pengisi pada carbon black biasanya bergantung pada interaksi Van der Waals yang dapat putus dengan mudah pada saat proses pencampuran, namun sebaliknya silika memiliki interaksi antar bahan pengisi yang lebih kuat karena adanya ikatan hidrogen selain interaksi Van der Waals dan interaksi fisika lainnya. Selain itu, silika sendiri tidak kompatibel dengan karet non-polar, seperti karet alam, styrene butadiene rubber (SBR) dan butadiene rubber (BR), karena silika memiliki gugus silanol pada permukaannya yang menyebabkan senyawa ini memiliki polaritas yang tinggi (Kantala et al., 2009). Penggunaan silika sebagai bahan pengisi pada jenis karet non-polar tanpa menggunakan kompatibiliser dikhawatirkan akan menghasilkan dispersi yang kurang baik dan berakibat pada turunnya sifat-sifat dari kompon yang dihasilkan sebagai efek dari interaksi antar bahan pengisi yang sangat kuat (Donnet, 1998). Selain itu, gugus polar pada permukaan silika dapat membentuk ikatan hidrogen dengan gugus polar lainnya yang berasal dari zat aditif seperti zat akselerator yang digunakan dalam pembuatan kompon. Proses ini akan memberikan efek negatif pada proses pematangan karet (Bachmann et al., 1959). Oleh karena itu, penggunaan kompatibiliser seperti silane coupling agents dalam penggunaan silika sebagai bahan pengisi sangat diperlukan untuk meningkatkan interaksi silika-karet, meningkatkan dispersi silika dan mencegah adsorpsi akselerator pada permukaan silika. Dalam penelitian ini digunakan bis[3(triethoxysilyl)propyl] Tetrasulfide (TESPT), yang merupakan produk komersial yang cukup banyak digunakan baik dalam skala penelitian maupun industri, untuk meningkatkan interaksi silika dan kemampuan dispersinya dalam karet (Goerl et al., 1997).

Sengloyluan et al. (2014), dalam penelitiannya, melakukan pengujian terhadap pengaruh penambahan silika pada karet alam dengan menggunakan karet alam terepoksidasi sebagai coupling agent. Hasil pengujian reologi dan sifat mekanis menunjukkan bahwa coupling agent komersial, yaitu TESPT, masih lebih unggul dibandingkan karet alam terepoksidasi. Pada penelitian ini, tinjauan reologi dan viskoelastis menjadi fokus utama karena kedua sifat ini sangat penting untuk memprediksikan sifat mekanis produk karet, serta berguna untuk memperoleh formulasi optimum dalam penelitian dan pengembangan suatu produk, terutama tread ban. Sebelum dilakukan pembuatan sampel skala laboratorium yang akan menghabiskan lebih banyak material dan membutuhkan waktu yang lebih lama, optimasi formulasi dengan melakukan pengujian sifat reologi dan viskoelastis diharapkan menjadi metode yang lebih efisien. Tujuan penelitian adalah untuk mengetahui sifat viskoelastis dan reologi dari kompon tread ban menggunakan bahan dasar karet alam (NR) dan BR dengan variasi komposisi bahan pengisi carbon black/silika. Pengembangan ini sangat diperlukan dalam proses pembuatan ban di Indonesia mengingat rendahnya kepercayaan masyarakat terhadap penggunaan ban retread yang sebenarnya jika diformulasi dengan baik akan memiliki kualitas yang sama dengan ban baru.

\section{BAHAN DAN METODE \\ Bahan Penelitian}

Bahan baku utama pada penelitian ini yaitu NR tipe RSS1 dengan densitas $0,95 \mathrm{~g} / \mathrm{cm}^{3}$ yang diperoleh dari pemasok lokal serta BR dengan viskositas Mooney 40 dan densitas $0,42 \mathrm{~g} / \mathrm{cm}^{3}$ yang diperoleh dari Goodyear Chemical. Bahan pengisi yaitu carbon black N220 dari Cabot dan silika highly dispersible dari Jebsen and Jessen Chemical serta bis-(3-triethoxysilyl-propyl)- 
Tabel 1. Desain formulasi.

\begin{tabular}{lrrrrr}
\hline & \multicolumn{5}{c}{ Formula (phr) } \\
\cline { 2 - 6 } & \multicolumn{1}{c}{ FS1 } & FS2 & FS3 & FS4 & \multicolumn{1}{c}{ FS5 } \\
\hline Karet alam & 85 & 85 & 85 & 85 & 85 \\
Butadiene rubber & 15 & 15 & 15 & 15 & 15 \\
Peptizer & 3 & 3 & 3 & 3 & 3 \\
Aktivator & 8 & 8 & 8 & 8 & 8 \\
Carbon black N220 & 50 & 40 & 25 & 10 & 0 \\
HD Silika & 0 & 10 & 25 & 40 & 50 \\
TESPT & 0 & 0,8 & 2 & 3,2 & 4 \\
Antidegradasi & 8 & 8 & 8 & 8 & 8 \\
Minyak pemroses & 6 & 6 & 6 & 6 & 6 \\
Kuratif & 3 & 3 & 3 & 3 & 3 \\
\hline
\end{tabular}

Jumlah phr TESPT dihitung berdasarkan persamaan berikut (Guy et al., 2009): TESPT (phr) $=0,00053 \mathrm{x}$ $\mathrm{Q}$ x A, dimana $\mathrm{Q}$ adalah jumlah silika (phr) dan A adalah CTAB area permukaan silika ( $\left.\mathrm{m}^{2} / \mathrm{g}\right)$.

tetrasulfide (TESPT) dari Evonik Jerman sebagai coupling agent. Bahan aditif terdiri dari peptizer jenis polioktanamer dari PT Evonik Indonesia, aktivator, antidegradasi, dan bahan kuratif dari Rhein Chemie.

\section{Peralatan Penelitian}

Peralatan yang digunakan untuk proses pembuatan kompon yaitu kneader skala laboratorium dengan kapasitas maksimum 3000 liter tipe Moriyama DS3-10MWB-E dan two roll mill LMS 09T. Viskositas Mooney ditentukan dengan Mooney Viscometer Professional Montech $\mathrm{GmbH}$ dan waktu kematangan optimum ditentukan menggunakan moving die rheometer (MDR) Montech GmbH. Rubber processing analyzer (RPA) TA Instrument type Elite digunakan untuk analisis sifat reologi sedangkan sifat viskoelastis diuji dengan menggunakan dynamic mechanical analyzer (DMA) 7100 Hitachi.

\section{Metode Penelitian}

Tabel 1 menunjukkan formulasi yang digunakan dalam penelitian ini dengan variasi bahan pengisi. Jumlah karet (RSS1 dan BR) untuk setiap formulasi adalah $100 \mathrm{phr}$. Pencampuran diawali dengan mastikasi RSS1 dan BR menggunakan peptizer di dalam kneader, dilanjutkan penambahan bahan pengisi dan bahan aditif termasuk minyak pemroses. Proses pencampuran dilakukan dalam kneader pada suhu $110^{\circ} \mathrm{C}$ dengan kecepatan pengadukan 60 rpm. Setelah homogen, dibiarkan selama 24 jam sebelum selanjutnya ditambahkan bahan kuratif dengan menggunakan kneader yang sama pada suhu $70^{\circ} \mathrm{C}$ dalam waktu maksimal 2 menit. Selanjutnya dilakukan pembentukan lembaran kompon untuk meningkatkan kekuatan tarik dan mempermudah proses selanjutnya menggunakan two roll mill (Wisojodharmo et al., 2017).

Viskositas Mooney (ML 1+4 (100)) kompon dianalisis pada suhu $100^{\circ} \mathrm{C}$ dan frekuensi $1,67 \mathrm{~Hz}$ dengan viskometer Mooney. Sedangkan waktu kematangan (curing time) dianalisis menggunakan MDR pada suhu $140^{\circ} \mathrm{C}$ dan frekuensi $1,67 \mathrm{~Hz}$. Sifat reologi selanjutnya dianalisis menggunakan RPA TA Instrument Elite. Pengujian dilakukan dengan variasi frekuensi dari $0,01-50 \mathrm{~Hz}$ pada suhu $100^{\circ} \mathrm{C}$ dengan amplitudo tetap $1^{\circ}$ dan variasi amplitudo dari $0,05-3,59$ pada suhu $90^{\circ} \mathrm{C}$ dengan frekuensi tetap $1 \mathrm{~Hz}$. Sifat viskoelastis dan suhu glass transition dianalisis menggunakan DMA dengan mode tension-compression pada rentang suhu $-80-80{ }^{\circ} \mathrm{C}$ dengan ukuran sampel $23,2 \mathrm{x}$ $3,2 \times 5,3 \mathrm{~mm}$.

\section{HASIL DAN PEMBAHASAN Viskositas Mooney}

Tabel 2 menunjukkan hasil pengujian viskositas Mooney (ML 1+4 (100)). Viskositas Mooney dari kelima formulasi dengan perbedaan jumlah phr bahan pengisinya tidak menunjukkan adanya perbedaan yang signifikan antara satu sama lain. Secara teori, adanya penambahan silika akan mengakibatkan peningkatan viskositas karena kuatnya interaksi antar bahan pengisi silika sehingga akan lebih sulit terdispersi jika dibandingkan dengan bahan pengisi carbon 
Tabel 2. Viskositas Mooney.

\begin{tabular}{cc}
\hline Nama Sampel & ML 1+4 (100) \\
\hline FS1 & 49,15 \\
FS2 & 51,23 \\
FS3 & 50,99 \\
FS4 & 51,79 \\
FS5 & 50,51 \\
\hline
\end{tabular}

black saja. Namun penggunaan TESPT sebagai kompatibiliser dengan reaksi antara gugus alkoksi-silil dan silika dapat menurunkan interaksi antar bahan pengisi sehingga selanjutnya dapat ditunjukkan dengan penurunan viskositas mooney yang mengartikan telah terbentuk kompon yang lebih homogen (Sengloyluan et al., 2014).

\section{Waktu kematangan kompon (t90)}

Crosslinking atau pembentukan ikatan silang dalam proses vulkanisasi dapat meningkatkan elastisitas serta kekuatan karet. Proses ini merupakan tahap utama dalam proses pembuatan produk karet dimana salah satu parameter yang harus diperhatikan adalah waktu. Waktu dan suhu tentunya bergantung pada jenis bahan baku yang digunakan serta curing system yang berperan dalam reaksi sehingga setiap akan komposisi memiliki waktu dan suhu yang spesifik. Proses vulkanisasi tidak boleh dilakukan terlalu lama melebihi waktu optimum karena dapat merusak struktur polimer dan ikatan silang yang ada dan tidak boleh terlalu singkat karena dapat menyebabkan vulkanisasi berjalan tidak sempurna bahkan berakibat adanya vulkanisasi lanjutan yang justru menurunkan kualitas produk nantinya.

Dalam menentukan waktu dan suhu optimum, digunakan instrumen reometer yang memiliki prinsip kerja memberikan energi dalam bentuk torsi ke dalam sampel sehingga timbul panas yang akan meningkatkan temperatur sampel. Selanjutnya sampel akan mengalami ikatan crosslinking ketika temperatur tepat pada nilai spesifik yang dibutuhkan. Reometer dapat digunakan untuk menentukan waktu yang efisien atau sering disebut sebagai t90 yang dapat dijadikan acuan dalam proses vulkanisasi tersebut.

Data 190 pada seluruh variasi dengan nilai yang berbeda-beda ditunjukkan di Gambar 1 . Nilai t90 ini menunjukan lamanya waktu untuk mematangkan $90 \%$ total kompon. Semakin banyak kandungan silika, maka waktu yang dibutuhkan untuk proses pematangan akan semakin lama. Hal

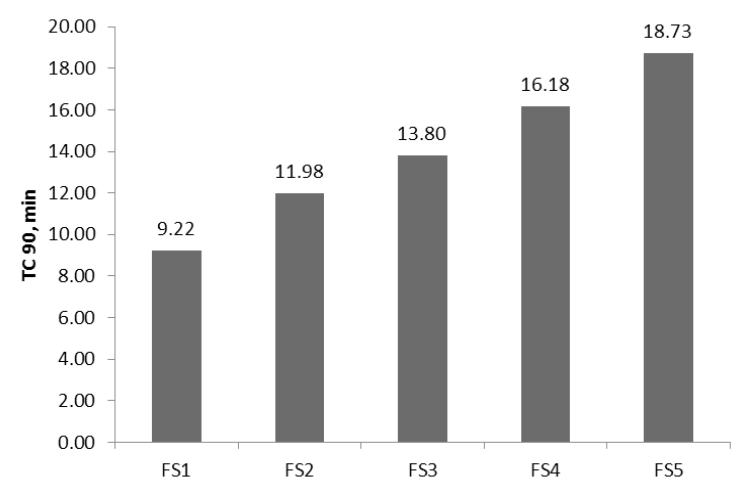

Gambar 1. Hasil pengujian waktu kematangan optimum.

ini terkait dengan interaksi antar bahan pengisi yang telah disebutkan sebelumnya. Selain itu, kandungan silika yang lebih banyak memerlukan waktu karena proses transfer energi panas dalam vulkanisasi yang terhambat mengingat silika merupakan isolator panas yang baik, berkebalikan dengan carbon black yang merupakan konduktor yang baik.

Krejsa dan Koenig (1993) memaparkan dengan berbagai literatur tentang mekanisme percepatan reaksi crossslinking pada karet dimana waktu tersebut dipengaruhi oleh akselerator dengan mekanisme masing-masing. Pada umumnya, waktu yang dibutuhkan untuk proses crosslinking pada karet dipengaruhi oleh beberapa faktor seperti konsentrasi sulfur, suhu, curing agent akselerator, dan beberapa faktor lain (Ciesielski, 1999). Namun dalam hal ini, konsentrasi bahan-bahan aditif tersebut sama, sehingga yang menjadi faktor penentu yaitu pada variasi bahan pengisi.

\section{Sifat reologi}

Salah satu parameter yang sangat penting untuk memprediksi sifat fisik suatu produk karet dari komponnya yaitu dengan mengetahui sifat reologi. Sifat reologi ini erat kaitannya dengan struktur kimia antara polimer karet dengan matriksnya maupun bahan aditif lainya dalam proses vulkanisasi. Sifat reologi suatu kompon juga dapat digunakan untuk mengidentifikasi crosslinking pada proses vulkanisasi.

Salah satu instrumen yang umum digunakan untuk menentukan sifat reologi yaitu adalah RPA. Instrumen ini dapat digunakan untuk menentukan karakteristik suatu bahan serta menganalisis proses vulkanisasi dan karakter masing-masing pada kompon. 


\section{Frequency sweep}

Pengujian frequency sweep atau memvariasikan frekuensi untuk mengetahui sifat viskoelastis dapat dilakukan dengan menggunakan alat RPA. Lain halnya dengan viskometer Mooney yang hanya dapat menghitung viskositas pada satu frekuensi, perubahan sifat pada kompon dapat diprediksikan dengan menggunakan RPA. Dengan melakukan variasi frekuensi, maka dapat diperoleh data mengenai shear modulus (G'), tan delta dan viskositas. Semakin tinggi tan delta, maka viskositas akan semakin rendah, yang artinya kompon lebih mudah untuk mengalir dan pada aplikasi tertentu akan lebih mudah untuk diproses misalnya pada proses lanjutan kalendering. Dari Gambar 2, 3, dan 4 dapat dilihat bahwa FS5 yang mengandung $50 \mathrm{phr}$ silika memiliki viskositas yang paling rendah sehingga dapat diproses dengan lebih mudah.

\section{Efek Payne}

Efek Payne sangat dipengaruhi oleh jenis bahan pengisi serta jumlah dan komposisi bahan pengisi yang digunakan. Pengujian untuk memperoleh perbedaan efek Payne dari masing-masing formulasi dilakukan dengan memvariasikan amplitudo pengujian untuk menghitung torsi pada kompon karet yang menunjukkan sifat viskoelastisnya. Semakin rendah efek Payne menandakan bahwa interaksi antar bahan pengisi yang semakin rendah dan menunjukkan dispersi antar molekul yang semakin baik di dalam kompon (Katueangngan et al., 2016).

Gambar 5 menunjukkan efek Payne pada komponyang belummatang (uncured). Efek Payne pada kompon yang belum matang menunjukkan seberapa baik bahan pengisi terdispersi di dalam polimer, dalam hal ini karet alam RSS1 dan karet sintetik BR. FS5 menunjukkan bahwa bahan pengisi telah terdispersi dengan baik ke dalam karet dan menghasilkan kompon yang homogen.

Seperti halnya dengan Gambar 5, Gambar 6 yang menunjukkan efek Payne pada sampel kompon yang sudah matang pun menunjukkan hasil optimum ditunjukkan oleh F5. Shear modulus (G') yang cukup rendah pada grafik mengindikasikan interaksi antar bahan pengisi yang cukup rendah. Kekuatan mekanis seperti kekuatan tarik pun dapat diprediksi dari hasil pengujian efek Payne pada sampel yang sudah matang. Semakin rendah efek Payne, maka akan

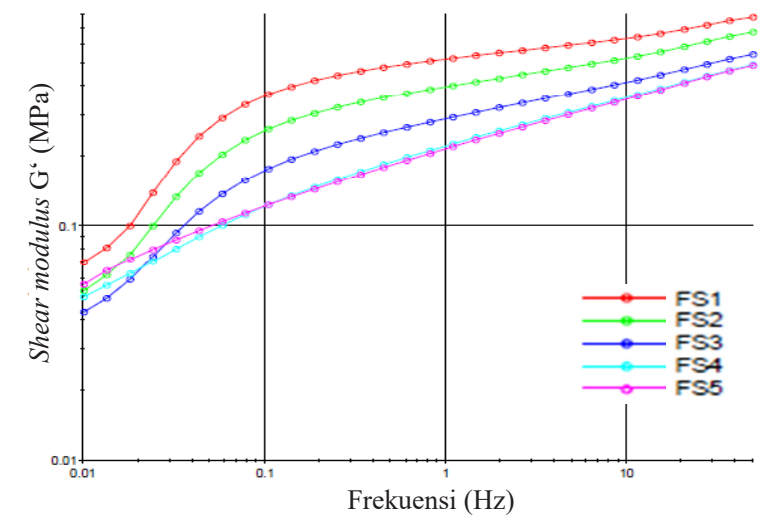

Gambar 2. Frekuensi vs shear modulus $\left(\mathrm{G}^{`}\right)$.

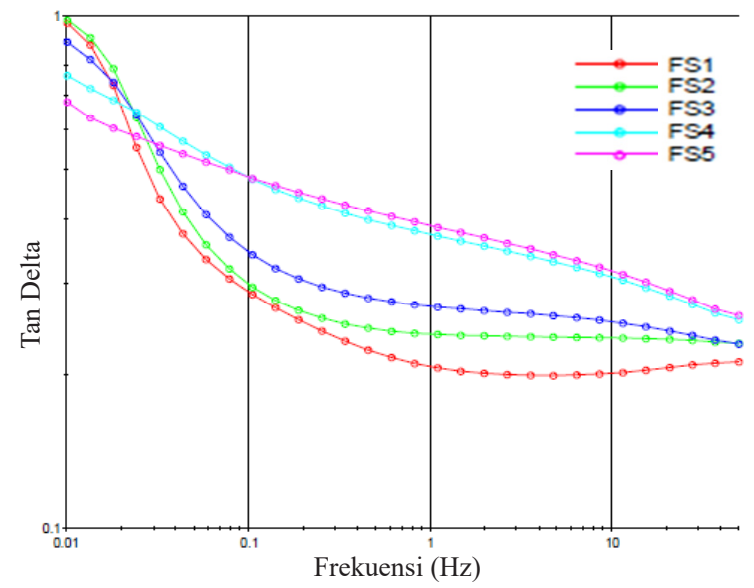

Gambar 3. Frekuensi vs Tan delta.

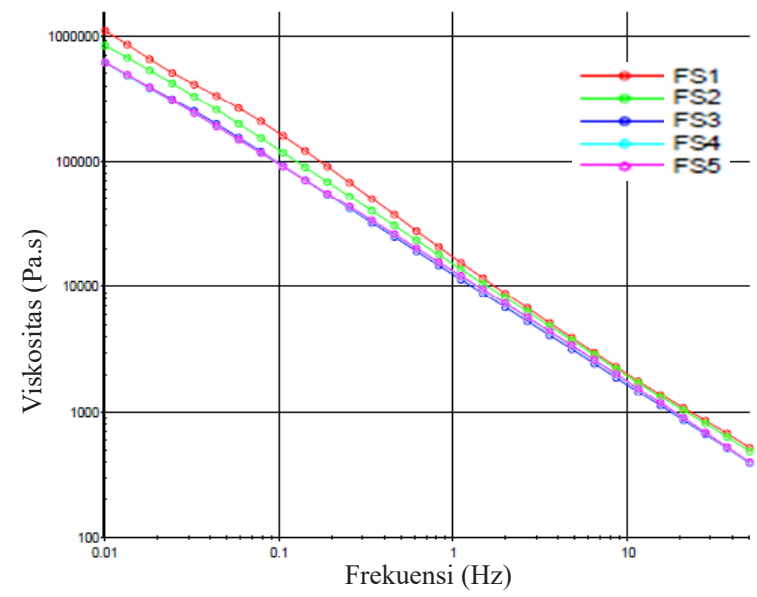

Gambar 4. Frekuensi vs viskositas.

terjadi peningkatan sifat mekanis. Selain itu, menurut Boonstra dan Medalia (1963), selain kekuatan tarik, akan terjadi penurunan heat build up, peningkatan ketahanan abrasi, peningkatan resistansi, penurunan kekerasan dan kekuatan sobek yang relatif konstan. 


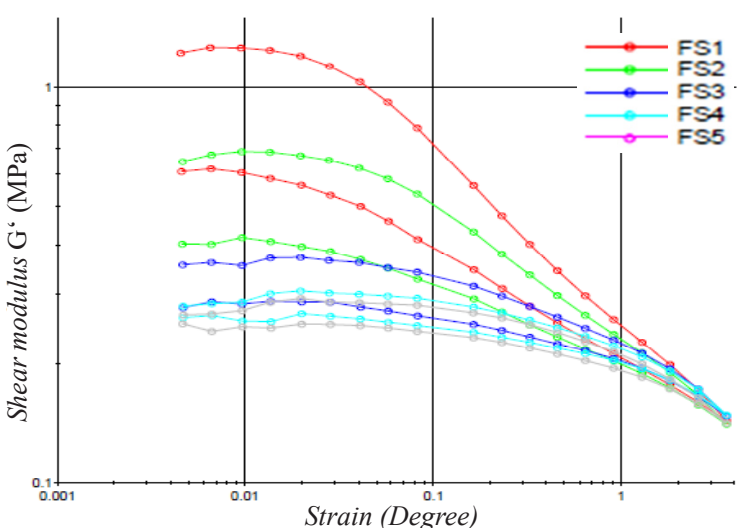

Gambar 5. Efek Payne pada sampel kompon uncured.

\section{Energi disipasi}

Energi disipasi diukur dari hasil pengujian dengan memvariasikan amplitudo dan hasilnya dapat dilihat pada Tabel 3 berikut. Penambahan silika terbukti dapat menurunkan energi disipasi dimana hal ini sangat penting untuk mempermudah pemrosesan karet.

\section{Sifat viskoelastis}

Sifat viskoelastis dapat dianalisa menggunakan DMA dimana sampel diuji pada suhu tertentu untuk mengetahui kekuatannya. Loss tangent atau yang biasa disebut sebagai tan $\delta$ pada suhu $60^{\circ} \mathrm{C}$ merupakan indikasi dari rolling resistance ban yang dapat dilakukan pengujiannya dalam skala laboratorium ( $\mathrm{Li}$ et al., 2016). Kompon yang memiliki tan $\delta @ 60^{\circ} \mathrm{C}$ yang lebih rendah artinya memiliki rolling resistance yang lebih baik. Seperti dapat dilihat pada Tabel 4,

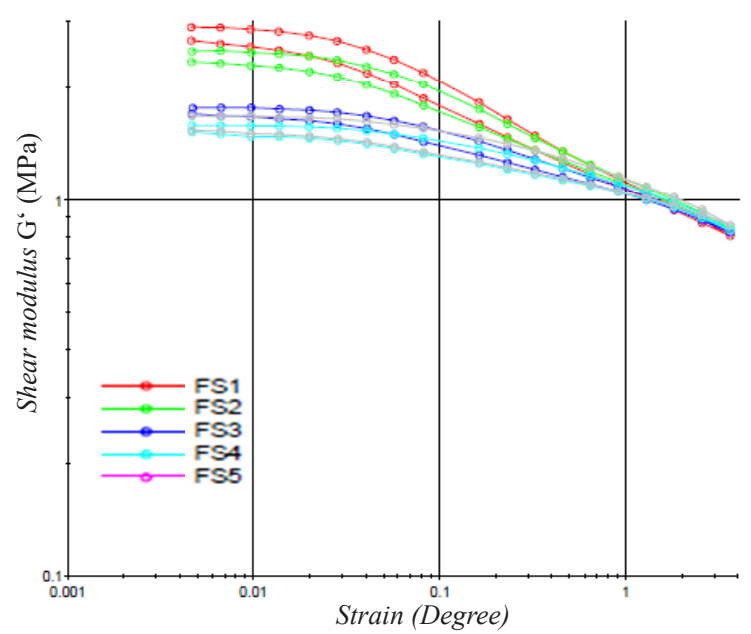

Gambar 6. Efek Payne pada sampel kompon cured.

semakin banyak jumlah silika, tan $\delta @ 60^{\circ} \mathrm{C}$ dan $\tan \delta @ 80^{\circ} \mathrm{C}$ semakin rendah, mengindikasikan bahwa bahan pengisi, baik silika maupun carbon black terdispersi dengan sempurna. Hal ini juga dipengaruhi adanya TESPT sebagai coupling agent yang meningkatkan ikatan silika dan karet melalui molekul silane. Sedangkan dari Gambar 7 juga dapat dilihat bahwa temperatur transisi gelas menurun dengan adanya penambahan silika. Temperatur transisi gelas pada suatu kompon menunjukkan titik dimana di bawah suhu tersebut kompon bersifat glassy dan di atasnya bersifat rubbery. Secara umum, untuk aplikasi tread ban, diharapkan temperatur transisi adalah sekitar $-60^{\circ} \mathrm{C}$, semakin rendah suhunya akan semakin

Tabel 3. Energi disipasi.

\begin{tabular}{llc}
\hline Formulasi & \multicolumn{2}{c}{ Energi disipasi (J) } \\
\cline { 2 - 3 } & Kompon uncured & Kompon cured \\
\hline FS1 & 1,2989 & 1,7377 \\
FS2 & 1,2186 & 1,6843 \\
FS3 & 1,1414 & 1,4149 \\
FS4 & 1,0922 & 1,3040 \\
FS5 & 1,0421 & 1,1143 \\
\hline
\end{tabular}

Tabel 4. Tan $\delta$ dan temperatur transisi gelas.

\begin{tabular}{|c|c|c|c|c|}
\hline Formulasi & $\tan \delta @ 0^{\circ} \mathrm{C}$ & $\tan \delta @ 60^{\circ} \mathrm{C}$ & $\tan \delta @ 80^{\circ} \mathrm{C}$ & $\mathrm{T} @ \tan \delta \max \left({ }^{\circ} \mathrm{C}\right)$ \\
\hline FS1 & 0,096 & 0,087 & 0,094 & -56.3 \\
\hline FS2 & 0,092 & 0,071 & 0,077 & -56.9 \\
\hline FS3 & 0,088 & 0,050 & 0,051 & -52.6 \\
\hline FS4 & 0,092 & 0,053 & 0,054 & -53.4 \\
\hline FS5 & 0,089 & 0,051 & 0,051 & -51.1 \\
\hline
\end{tabular}




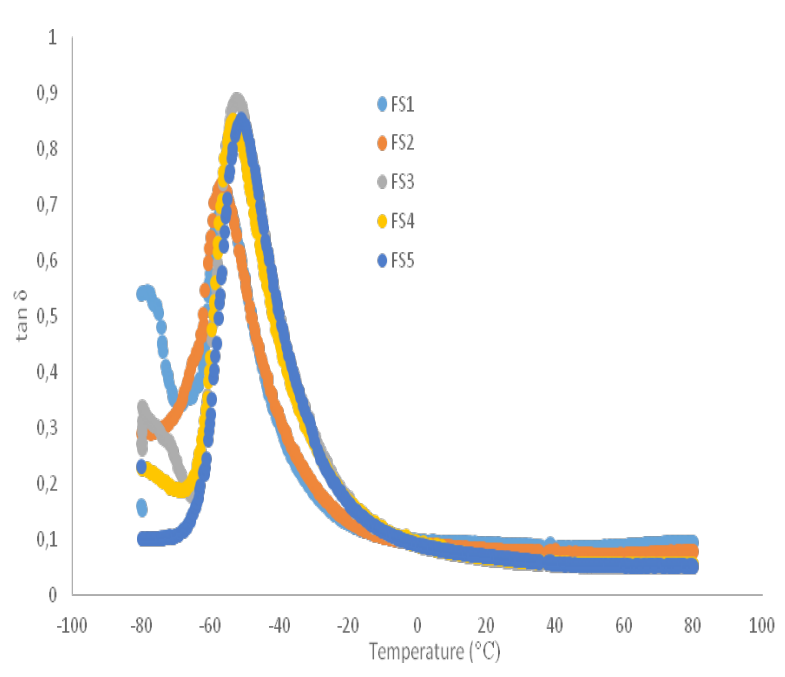

Gambar 7. Hasil pengujian DMA (temperatur vs $\tan \delta)$.

baik karena memungkinkan aplikasi di suhu yang lebih rendah.

\section{KESIMPULAN}

Hasil penelitian menunjukkan bahwa penambahan silika memberikan perbedaan signifikan pada efek Payne yang menunjukkan interaksi antar bahan pengisi. Penurunan energi disipasi yang linear dengan penambahan silika juga menunjukkan kecenderungan penurunan heat build up, peningkatan sifat mekanis seperti kekuatan tarik dan memperbaiki ketahanan abrasi pada produk karet. Hal ini didukung oleh hasil uji viskoleastis dengan DMA dimana diperoleh loss tangent yang lebih rendah pada penambahan silika yang mengindikasikan peningkatan rolling resistance. Selain itu, peningkatan komposisi silika juga menurunkan temperatur transisi gelas yang memungkinkan aplikasi tread ban pada suhu yang lebih rendah. Berdasarkan tinjauan reologi dan viskoelastis, penggunaan silika direkomendasikan untuk aplikasi tread ban dibandingkan hanya dengan menggunakan carbon black saja. Untuk itu, perlu dilakukan penelitian lebih lanjut dengan meningkatkan skala penelitian dan produksi untuk efisiensi ekonomi serta ketahanan dari produk sehingga dapat dipertimbangkan untuk proses komersialisasi.

\section{UCAPAN TERIMA KASIH}

Penulis mengucapkan terima kasih kepada Pusat Teknologi Material Badan Pengkajian dan Penerapan Teknologi atas dana penelitian serta beasiswa Riset-Pro Non Degree dari Kementerian
Riset, Teknologi dan Pendidikan Tinggi yang telah membiayai pelatihan di University of Akron terkait penelitian ini.

\section{DAFTAR PUSTAKA}

Bachmann, J. H., Sellers, J. W., Wagner, M. P., \& Wolf, R. F. (1959). Fine particle reinforcing silicas and silicates in elastomers. Rubber Chemistry and Technology, 32(5), 1286-1391. https://doi.org/10.5254/1.3542491

Boonstra, B. B., \& Medalia, A. I. (1963). Effect of carbon black dispersion on the mechanical properties of rubber vulcanizates. Rubber Chemistry and Technology, 36(1), 115-142. https://doi.org/10.5254/1.3539530

Ciesielski, A. (1999). An introduction to rubber technology. Rapra Technology Limited, United Kingdom.

Donnet, J. B. (1998). Black and white fillers and tire compound. Rubber Chemistry and Technology, 71(3), 323-341. https://doi.org/10.5254/1.3538488

Goerl, U., Hunsche, A., Mueller, A., \& Koban, H. G. (1997). Investigations into the silica/silane reaction system. Rubber Chemistry and Technology, 70(4), 608-623. https://doi.org/10.5254/1.3538447

Guy, L., Daudey, S., Chocet, P., \& Bomal, Y. (2009). New insight in the dynamic properties of precipitated silica filled rubber using a new high surface silica. Kautschuk Gummi Kunststoffe, 62(7-8), 383-391.

Kantala, C., Wimolmala, E., Sirisinha, C., \& Sombatsompop, N. (2009). Reinforcement of compatibilized NR/NBR blends by fly ash particles and precipitated silica. Polymer Advanced Technology, 20(5), 448-458. https://doi.org/10.1002/pat.1293

Katueangngan, K., Tulyapitak, T., Saetung, A., Soontaranon, S., \& Nithi-uthai, N. (2016). Renewable interfacial modifier for silica filled natural rubber compound. Procedia Chemistry. 19, 447-454. https://doi.org/10.1016/j.proche.2016.03.037

Krejsa, M. R., \& Koenig, J. L. (1993). A review of sulfur crosslinking fundamentals for accelerated and unaccelerated vulcanization. Rubber Chemistry and Technology. 66(3), 376-410. https://doi.org/10.5254/1.3538317

Li, Y., Han, B., Wen, S., Lu, Y., Yang, H., Zhang, L., \& Liu, L. (2014). Effect of the temperature on surface modification of silica and properties of modified silica filled rubber composites. Composites Part A: Applied Science and Manufacturing, 62, 5259.

Sengloyluan, K., Sahakaro, K, Dierkes, W. K., \& Noordermeer, J. W. M. (2014). Silica-reinforced tire tread compounds compatibilized by using 
epoxidized natural rubber. European Polymer Journal, 51, 69-79.

https://doi.org/10.1016/j.eurpolymj.2013.12.010

Seyvet, O., \& Navard, P. (2000). Collision-induced dispersion of agglomerate suspensions in a shear flow. Journal of Applied Polymer Science, 78, 1130-1133.
Wisojodharmo, L. A., Fidyaningsih, R., Fitriani, D. A., Arti, D. K., Indriasari, I., \& Susanto, H. (2017). The influence of natural rubber-butadiene rubber and carbon black type on the mechanical properties of tread compound. IOP Conference Series: Material Science and Engineering. 